\title{
Engineering geological characteristics based on rock mass rating (RMR) and geological strength index (GSI) in Tunnel Number 1 of the Sigli-Aceh toll road
}

\author{
Jabnes Satria ${ }^{1,2}$, I Gde Budi Indrawan ${ }^{1 *}$, and Nugroho Imam Setiawan ${ }^{1}$ \\ ${ }^{1}$ Geological Engineering Departement, Engineering Faculty, Gadjah Mada University, Sleman, Yogyakarta, Indonesia \\ ${ }^{2}$ PT. Hutama Karya (Persero), Jakarta, Indonesia
}

\begin{abstract}
This paper presents engineering geological investigation results in the form of rock mass characteristics for tunnel number 1 of the Sigli-Aceh toll road. The investigation was carried out through geological mapping, core drill evaluation, and laboratory tests. In this research, the rock mass rating (RMR) and Geological Strength Index (GSI) were applied for the rock mass classifications. The measurement of rock mass quality is then used to determine the excavation method and tunnel support system on the SigliAceh toll road. The results showed that the research location consisted of calcareous sandstone with poor to good-quality (GSI (21.7 - 85.5), RMR (32.0 - 67.6)), and sandstone with good quality (GSI (86.3 - 86.9), RMR (64.0 - 65.0)). The poor quality rock masses were mainly caused by weathering effect. In addition, this research also analyzes the relationship between RMR and GSI based on the type and quality of rocks in the research location so that this correlation can be used in other areas with similar rock type and quality to this research location.
\end{abstract}

\section{Introduction}

Tunnel construction development is the most appropriate alternative to protect the environment and support the principles of sustainable development [1]. Tunnel construction development with sustainable development is currently being developed in Indonesia through the Ministry of Public Works and Housing (PUPR). Land problems have always been obstacles in development, such as roads, bridges, and other civil constructions. The problem of travel time, geological conditions, and various topographies of Indonesia, such as lowlands, hills, and mountains, is the determining factor for tunnel construction. One of the tunnels to be built is tunnel number one of the Sigli-Aceh toll road. The construction of this tunnel is located in Padang Tiji District, Pidie Regency, Aceh Province (Fig. 1).

Morphological units in the research location based on Brahmantyo et al. [2], which are homocline hills and homocline valleys in the Paguhulu River. Homocline hills have a slope of more than $35 \%$ with a steep category and the potential for landslides to occur on the slopes if tunnel excavation is carried out.

Several site investigations had carried out in the tunnel construction design stage. However, the engineering geological characteristics of rock mass at the research location have not been carried out in detail. The rock mass characteristics can be carried out through engineering geological investigations in the form of engineering geological mapping, core drill evaluation, and laboratory testing to determine the rock mass engineering classification.

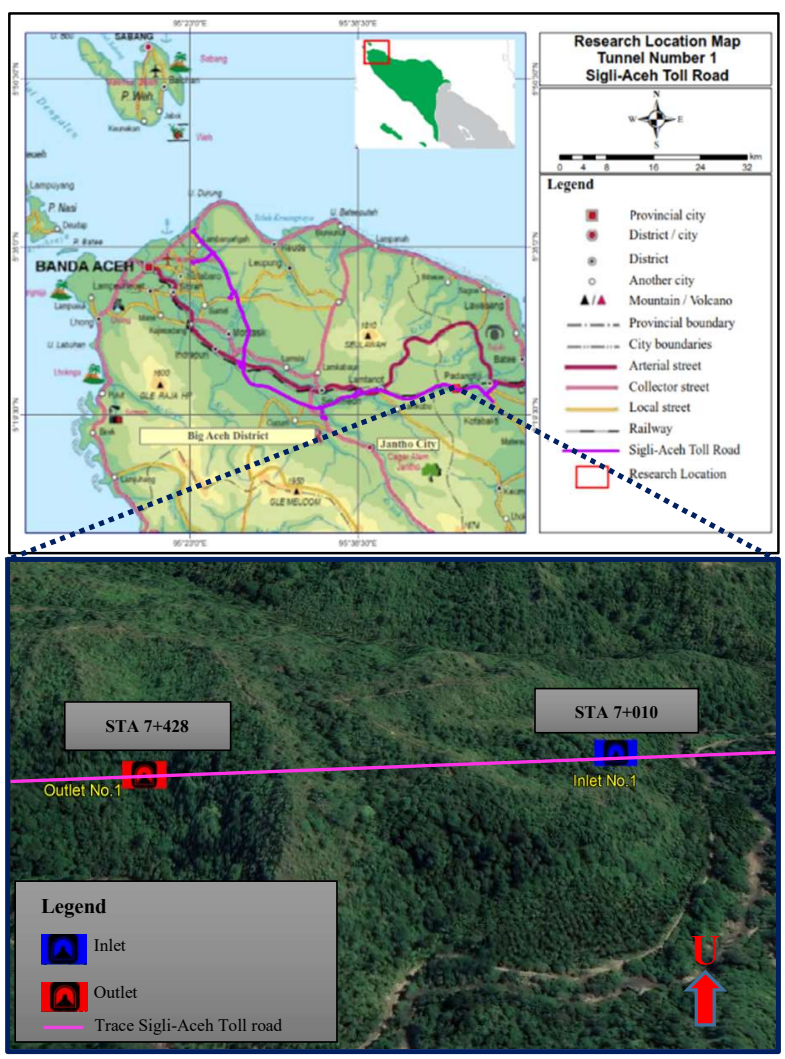

Fig. 1. Location of tunnel number 1 Sigli-Aceh toll road.

\footnotetext{
* Corresponding author: igbindrawan@ugm.ac.id
} 
Rock mass engineering classification is an essential step to determining the excavation method and the stability of the tunnel. The rock mass rating (RMR) and Geological Strength Index (GSI) are the two most widely used rock mass classifications of the other rock mass classification systems. The rock mass rating (RMR) and Geological Strength Index (GSI) are very useful in determining different rock conditions. The empirical research to test the correlation between the rock mass of RMR and GSI was conducted previously [3, 16] by emphasizing its application for tunnel construction. Because the rock mass characteristics significantly affect the excavation method and the stability of the tunnel, it is necessary to carry out detailed research on the engineering geological characteristics based on the rock mass of RMR and GSI, that these rock mass classification has never been used before at this research location. In addition, the correlation between the rock mass RMR and GSI subsurface in Tunnel number 1 on the Sigli-Aceh toll road needs to be conducted so that the correlation results can be applied to other areas that having similar rock types and qualities with the research location.

\section{Geological conditions}

\subsection{Lithology}

The Banda Aceh Geological Map Sheet with a scale of 1: 250,000 was prepared by Bennet et al. [5] showed that the research location and its surroundings have a regional stratigraphy with an old to the young sequences consisting of the Meucampli Formation (Tlm), the Padangtiji Formation (Tuktp), the Kotobakti Formation (Tukt), the Seulimeum Formation (QTps), Lam Teuba Volcanic Rocks (QTvt), and Alluvium (Qh). The main formation types found at this research location are members of the Padangtiji Formation. At the tunnel location, there is one rock unit, namely calcareous sandstone with a sandstone interlayer. While for the lithology, it consists of calcareous sandstone and sandstone (Fig. 2).

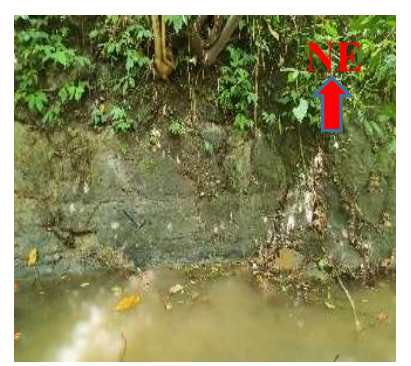

(a)

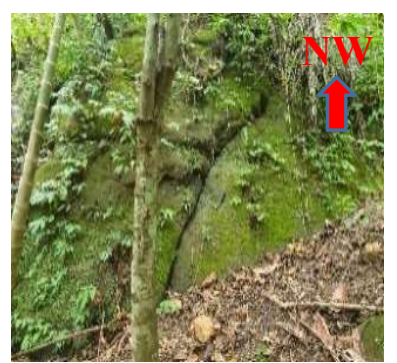

(b)
Fig. 2. Rock types from observations on outcrops at the research location: a) calcareous sandstone; b) sandstone.

\subsection{Geological structure}

The geological structure in Aceh Province based on the Hazard Map and Earthquake Sources of Indonesia [6] consists of two active faults: Nicobar Seulimeum-North and Aceh-North. Based on the interpretation of the Digital Elevation Model (DEM) map for the research location, it was found that there were dextral shear faults trending northeast-southwest. In addition, based on the measurement results of rock layers in the field, there are also two different directions of rock layers, namely the northeast and southeast. So that at the research location, there is an estimate of dextral shear faults.

\section{Methodology}

\subsection{Sample collections and field parameters}

The data used in this research consisted of engineering geological mapping, core drills, and laboratory results from subsurface samples. Analysis of rock mass quality at the research site used subsurface data from the results of drilling carried out as many as five boreholes, namely TB-11B with a depth of $40 \mathrm{~m}$, TB-13B1 with a depth of $50 \mathrm{~m}, \mathrm{~TB}-15 \mathrm{~B}$ with a depth of $30 \mathrm{~m}, \mathrm{~TB}-16 \mathrm{~B}$ with a depth $60 \mathrm{~m}$, and TB-17B with a depth of $50 \mathrm{~m}$. Laboratory testing is carried out directly from drilling results according to the lithology and weathering degree of the rock [7]. Tests were conducted in the form of soil and rock index properties [8] and rock uniaxial compressive strength (UCS) [9]. This test is carried out to obtain the parameters used to determining engineering geological characteristics based on Rock Mass Rating (RMR) and Geological Strength Index (GSI).

\subsection{Rock mass classification systems}

\subsubsection{Rock Mass Rating (RMR)}

Rock Mass Rating (RMR) is an engineering classification of rock mass often used for practical purpose in the engineering works [10]. Rock mass rating (RMR) has six parameters used for classifying the rock mass, namely 1) uniaxial compressive strength (UCS); 2) designation of rock quality (RQD); 3) spacing of discontinuity; 4) condition of discontinuity; 5) conditions of groundwater; and 6) orientation of discontinuity. These parameter can be used to obtain the rock mass quality of RMR at the research location. Besides, the RMR classification can also determine the tunnel stand-up time, which is the safe time for the tunnel after excavation without any reinforcement. The RMR classification can also determine the excavation method and tunnel support systems according to the rock mass class.

\subsubsection{Geological Strength Index (GSI)}

The Geological Strength Index (GSI) is a suitable method for determining rock mass quality in bad conditions with a high weathering degree. According to Marinos and Hoek [11], the Geological Strength Index (GSI) can be determined directly from the outcrop 
covering two main parameters, namely the condition of the structure (structure) and the condition of its surface (surface condition). In this research, the GSI value was determined based on subsurface data from the results of drilling carried out at the tunnel location. Calculation of subsurface GSI, according to Hoek et al. [12], can be determined using the relationship between Joint Condition [10] and the value of Rock Quality Designation (RQD) [3]. The subsurface GSI value can be calculated using the following equation:

$$
G S I=1.5 \operatorname{JCond}_{89}+R Q D / 2
$$

\subsubsection{Correlation of RMR and GSI}

The rock mass quality of RMR and GSI has a very close relationship because GSI parameters are generally based on RMR. The rock mass classification based on GSI is a development of RMR. Hoek and Brown [13] explain that the RMR classification based on Bieniawski [10] can estimate the GSI value as in the 1976 version. In this situation, the rating of the groundwater in dry conditions is equal to 15 , and the orientation of the discontinuity is equal to 0 . The minimum value for the classification of the rock mass of RMR is 23 , according to Bieniawski [10]. The final weight of this rock mass classification is called $\mathrm{RMR}_{89}$ and can be used to estimate the GSI value. If the value is $\mathrm{GSI} \geq 18$ or $\mathrm{RMR} \geq 23$, then:

$$
R M R_{89}=G S I+5
$$

Besides, Zhang et al. [4] have also examined the rock mass quality relationship between RMR and GSI. This research was conducted to determine the correlation value between the rock mass of RMR and GSI through the latest $\mathrm{RMR}$ called $\mathrm{RMR}_{14}$ [14] by considering the uniaxial compressive strength (UCS) value and the properties of the intact rock. Based on the Monte Carlo simulation method, the quantitative correlation of RMR and GSI for UCS values ranging from $9.08 \mathrm{MPa}<\mathrm{UCS}$ $<74.87 \mathrm{MPa}$ can be simplified into the following equation:

$$
\begin{aligned}
R M R_{14}= & 0.642 G S I+0.494 U C S^{0.65}+0.179 U C S \\
& +11.985 \\
R M R_{89}= & \left(R M R_{14}-2\right) / 1.1=0.584 G S I+0.449 U C S^{0.65} \\
& +0.163 U C S+9.077
\end{aligned}
$$

For the UCS value $\leq 9.08$, then:

$$
\begin{aligned}
R M R_{14}= & 0.642 G S I+0.494 U C S^{0.65}+13.365 \\
R M R_{89}= & \left(R M R_{14}-2\right) / 1.1=0.584 G S I+0.449 U C S^{0.65}+ \\
& 12.150
\end{aligned}
$$

\section{Results and discussion}

The results of geological mapping in the form of observations on rock outcrops show that there is one rock unit, namely calcareous sandstone, with a sandstone interlayer. While for the lithology, it consists of calcareous sandstone and sandstone. For rock units and the rock layer directions at the research, location can be seen in Figure 3, while the geological section can be seen in Figure 4.

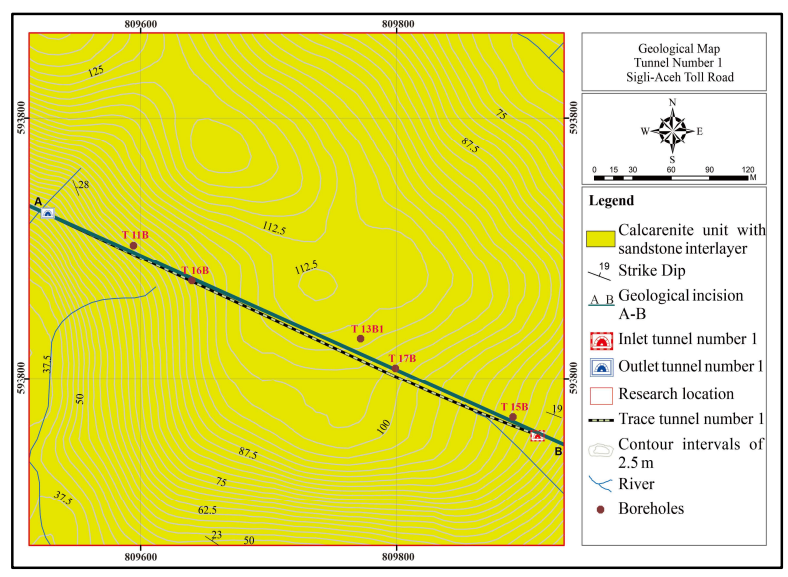

Fig. 3. Geological map of the research location.

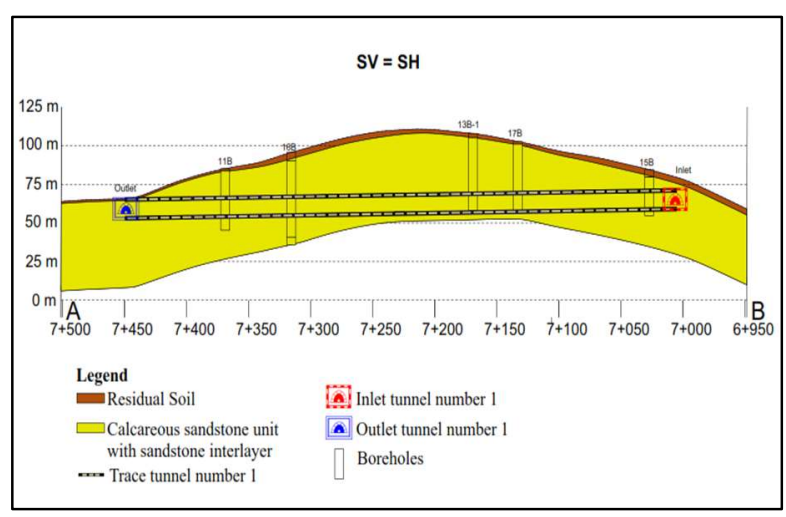

Fig. 4. Geological cross-section of A - B.

The rock mass classification used in determining the engineering geological characteristics is strongly influenced by rock discontinuities in the form of weathering degrees and joints. In this research, each borehole has rock discontinuities with high to slight weathering degrees. The rock discontinuity in the form of joints is directly proportional to the weathering degree. The higher the weathering degree at each borehole, the greater the number of joints. The weathering degree and joints have an important role in determining the quality of rock mass. The higher the weathering degree and joints in the rock, the worse the rock mass quality will be. Conversely, the lower the weathering degree and joints in the rock, the better the rock mass quality.

Boreholes of T-11B and T-15B are located at the inlet and outlet of the tunnel. The tunnel location at these boreholes has rock discontinuities with moderate weathering degrees. The boreholes of T-13B1, T-16B, and $\mathrm{T}-17 \mathrm{~B}$ are located in along the tunnel alignment. The tunnel location at these boreholes has rock discontinuities with slight weathering degrees. The difference in the weathering degree at the borehole is due to the tunnel position from the topographic surface. For the tunnel position close to the topographic surface, so the rock discontinuities on that tunnel have a high 
weathering degree because these rocks are repeatedly exposed for a long time due to weather fluctuation and laboratory results at each borehole, the slake endurance test value is SDI $<60 \%$. Based on the Gamble classification [15], the SDI value $<60 \%$ is low to very low durability, which indicates that the material will be very easily weathered into such as residual soil when exposed or when a flow of water enters the tunnel during excavation. If it is not reinforced immediately by shotcrete (to prevent direct contact with the atmosphere), the spalling or ravelling can occur at the walls and roof of the tunnel, which causing instability of the tunnel construction.

Based on rock discontinuity factors in the form of weathering degree and joints at the research location, the GSI rock mass quality from subsurface data (boreholes) has rock discontinuities with high to slight weathering degrees. The GSI rock mass quality [12] at the research location, based on its lithology, consists of calcareous sandstones with GSI values ranging from 21.7 to 85.5 and sandstones ranging from 86.3 to 86.9. Meanwhile, the RMR rock mass quality from the subsurface data (boreholes) has poor to good quality. The RMR rock mass [10], based on its lithology, consists of calcareous sandstone with RMR values ranging from 32.0 to 67.6 and sandstones ranging from 64.0 to 65.0 .

The rock mass quality at the tunnel location (tunnel elevation) based on RMR and GSI has moderate to good quality. For GSI, rock mass values [12] ranged from 48.4 to 85.5 . Meanwhile, the RMR rock mass [10] ranged from 46.9 to 67.6 . In addition to rock discontinuities in the form of weathering degree and joints, the strength of intact rock material like the uniaxial compressive strength test also influences the rock mass quality. The uniaxial compressive strength value at the research location ranges from 0.352 to 9.32 $\mathrm{MPa}$ and is classified as weak to extremely weak. The rock mass quality and the weathering degree for each borehole can be seen in Figure 5, and the drill core material can be seen in Figure 6. While the engineering geological characteristics of rock mass at the research location based on lithology can be seen in Table 1 .

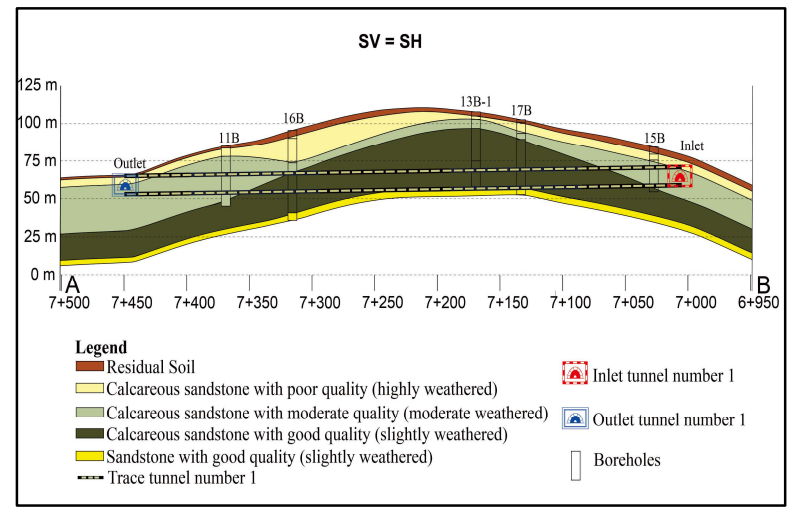

Fig. 5. The rock mass quality and the weathering degree for each borehole.

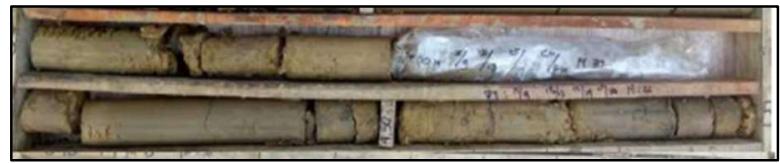

(a)

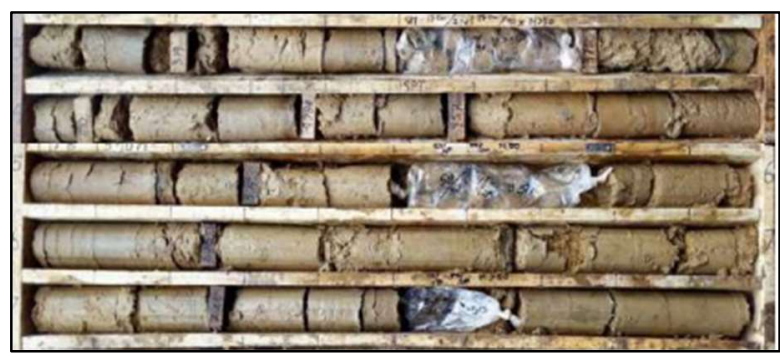

(b)

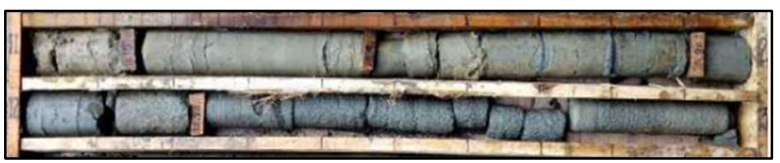

(c)

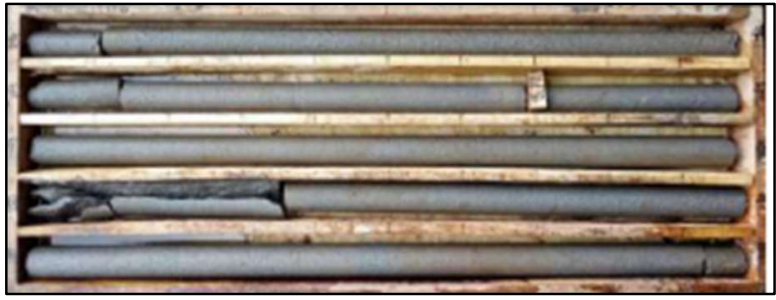

(d)

Fig. 6. Typical drill cores at the research location, material: a) residual soil; b) poor quality calcareous sandstone (highly weathered); c) fair quality calcareous sandstone (moderate weathered); d) good quality sandstone (slightly weathered).

The rock mass quality at the tunnel site is also very important to determine the most appropriate excavation method and tunnel support system. Using the RMR rock mass classification, we can determine an easy and safe excavation method for the tunnel. Tunnel excavation will be easier and safer if the tunnel axis is in the direction of the rock layer. Based on Figure 3, the research location generally has rock layers dipping to the northeast with an average angle of above $20^{\circ}$. For the tunnel axis parallel to strike with a rock dipping angle of $20-45^{0}$, it will be fair favourable if tunnel excavation is carried out [10]. So, the tunnel construction will be quite easy and safe if carried out at this research location.

In addition, this research also analyzes the relationship between RMR and GSI. This correlation is carried out and can be used as reference in other areas that having similar rock types and quality with this research location. These correlations will be compared with Hoek and Brown [13] and Zhang et al. [4]. The correlation between the rock mass of RMR and GSI in the research location can be expressed by the following equation (Fig. 7). 
The comparison of rock mass values based on the classification of RMR [10], GSI [12], correlation of RMR and GSI according to [13] and [4] can be seen in Table 2. Based on equation 7, the calculation of the subsurface rock mass quality based on the correlation between the rock mass of RMR and GSI at the research location generally has similarities with Zhang et al. [4]. Meanwhile, when compared with the correlation according to Hoek and Brown [13], there are some differences in rock mass quality. Hence the correlation between the rock mass of RMR and GSI, according to Zhang et al. [4], can be used at this research location and in other areas with similar rock types and qualities.

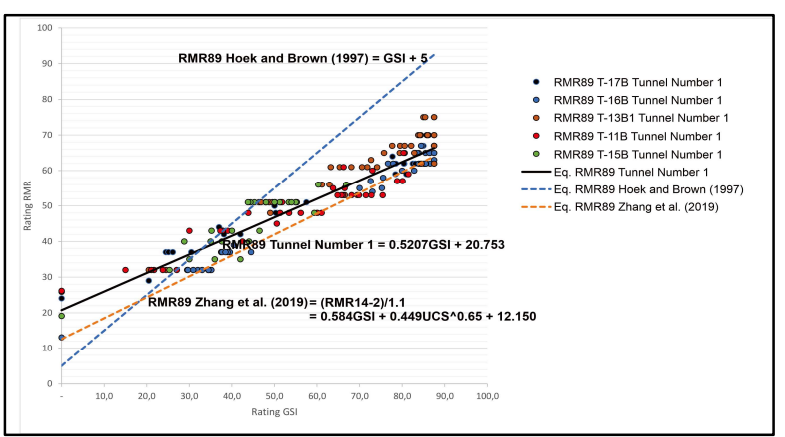

Fig. 7. The correlation equation $\mathrm{RMR}_{89}$ and GSI at the research location and comparison between correlation RMR89 and GSI at the research location with Hoek and Brown [13] and Zhang et al. [4]

\section{Conclusions and recommendations}

The tunnel number 1 of the Sigli-Aceh toll road consists of one rock unit, namely calcareous sandstone, with a sandstone interlayer. While for the lithology, it consists of calcareous sandstone and sandstone. The rock mass classification that will be used in determining the engineering geological characteristics is strongly influenced by rock discontinuities in the form of weathering degrees and joints. In addition, the uniaxial compressive strength also affects the rock mass quality. Rock mass based on the subsurface data (boreholes) has rock discontinuities with high to slight weathering degrees with uniaxial compressive strength (UCS) values ranging from 0.352 to $9.32 \mathrm{MPa}$ classified as weak to extremely weak. The GSI rock mass [12] values based on lithology consist of calcareous sandstones with GSI values ranging from 21.7 to 85.5 and sandstones ranging from 86.3 to 86.9 .

Meanwhile, the RMR rock mass quality from the subsurface data (boreholes) has poor to good quality. The RMR rock mass [10] values based on lithology consist of calcareous sandstone with RMR values ranging from 32.0 to 67.6 and sandstones ranging from 64.0 to 65.0 . The rock mass quality at the tunnel site is also very influential in determining the excavation method and tunnel support system. The direction and angle of the rock slope are very influential on the construction of the tunnel. The tunnel construction at the research location based on RMR rock mass [10] will be fair favourable because the tunnel axis parallel to strike with a rock dipping angle is above $20^{\circ}$.
The correlation of RMR and GSI rock mass at the research location $\left(R M R_{89}=0.5207 G S I+20.753\right)$ has a fairly good result because it has the same rock mass quality as the RMR and GSI correlation, according to Zhang et al. [4]. Meanwhile, compared with the correlation between the rock mass of RMR and GSI Hoek and Brown [13], there are several differences in rock mass quality because the correlation does not consider the value of uniaxial compressive strength (UCS) and intact rock properties. Therefore the correlation between the rock mass of RMR and GSI at the research location and according to Zhang et al. [4], can be used in other areas with similar rock types and quality to this research location.

Further research is needed, including determining the excavation method, and support system of tunnel number 1 on the Sigli-Aceh toll road based on the results of the rock mass characteristics in this research.

Table 1. Engineering geological characteristics of rock mass based on the lithology of the research location

\begin{tabular}{|c|c|}
\hline Lithology & Characteristics \\
\hline $\begin{array}{c}\text { Calcareous } \\
\text { sandstone } \\
\text { with poor } \\
\text { quality }\end{array}$ & $\begin{array}{l}\text { The rock is whitish-grey color, grain size } \\
\text { (fragment: } 0.1-0.5 \mathrm{~mm} \text {; matrix: }<0.1 \mathrm{~mm} \text { ), } \\
\text { rounded grain shape, closed packaging, fine } \\
\text { sorting, sediment structure of bedding, } \\
\text { composition: quartz, feldspar, biotite, lithic, } \\
\text { calcareous material, and siliciclastic } \\
\text { material. This lithology has a high level of } \\
\text { weathering, GSI values } 21.7-35.8, \mathrm{RMR} 89 \\
32.0-39.0 \text {, UCS }<1 \mathrm{Mpa} \text {. Water content } \\
\begin{array}{l}13.06 \%, \text { dry density } 1.397 \mathrm{gr} / \mathrm{cm}^{3} \text {, wet } \\
\text { density } 1.580 \mathrm{gr} / \mathrm{cm}^{3} \text {. }\end{array}\end{array}$ \\
\hline $\begin{array}{l}\text { Calcareous } \\
\text { sandstone } \\
\text { with } \\
\text { moderate } \\
\text { quality }\end{array}$ & $\begin{array}{l}\text { The rock is whitish-grey color, grain size } \\
\text { (fragment: } 0.1-0.5 \mathrm{~mm} \text {; matrix: }<0.1 \mathrm{~mm} \text { ), } \\
\text { rounded grain shape, closed packaging, fine } \\
\text { sorting, sediment structure of bedding, } \\
\text { composition: quartz, feldspar, biotite, lithic, } \\
\text { calcareous material, and siliciclastic } \\
\text { material. This lithology has a moderate level } \\
\text { of weathering, GSI values } 48.4-48.7, \mathrm{RMR} 89 \\
46.9-51.0, \mathrm{UCS} \text { ranges from } 1-5 \mathrm{Mpa} \text {. Water } \\
\text { content } 14.24 \%, \mathrm{dry} \mathrm{density} 1.628 \mathrm{gr} / \mathrm{cm}^{3} \text {, } \\
\text { wet density } 1.860 \mathrm{gr} / \mathrm{cm}^{3} \text {. }\end{array}$ \\
\hline $\begin{array}{l}\text { Calcareous } \\
\text { sandstone } \\
\text { with good } \\
\text { quality }\end{array}$ & $\begin{array}{l}\text { The rock is whitish-grey color, grain size } \\
\text { (fragment: } 0.1-0.5 \mathrm{~mm} \text {; matrix: }<0.1 \mathrm{~mm} \text { ), } \\
\text { rounded grain shape, closed packaging, fine } \\
\text { sorting, sediment structure of bedding, } \\
\text { composition: quartz, feldspar, biotite, lithic, } \\
\text { calcareous material, and siliciclastic } \\
\text { material. This lithology has a slight level of } \\
\text { weathering, GSI values } 65.7-74.4, \mathrm{RMR} 89 \\
61.9-67.6 \text {, UCS ranges from } 5-25 \mathrm{Mpa} \text {. } \\
\text { Water content } 7.62 \% \text {, dry density } 1.6775 \\
\mathrm{gr} / \mathrm{cm}^{3} \text {, wet density } 1.910 \mathrm{gr} / \mathrm{cm}^{3} \text {. }\end{array}$ \\
\hline $\begin{array}{c}\text { Sandstone } \\
\text { with good } \\
\text { quality }\end{array}$ & $\begin{array}{l}\text { The rock is Brownish color, grain size } \\
\text { (fragment: } 0.1-0.5 \mathrm{~mm} \text {; matrix: }<0.1 \mathrm{~mm} \text { ), } \\
\text { rounded grain shape, closed packaging, } \\
\text { good sorting, massive sedimentary } \\
\text { structure, composition: quartz, feldspar, } \\
\text { biotite, lithic, a siliciclastic material. This } \\
\text { lithology has a slight level of weathering, } \\
\text { GSI values } 86.3-86.9 \text {, RMR } 8964.0-65.0 \text {, } \\
\text { UCS ranges from 5-25 Mpa. Water content } \\
9.56 \% \text { dry density } 1.920 \mathrm{gr} / \mathrm{cm}^{3} \text {, wet } \\
\text { density } 2.104 \mathrm{gr} / \mathrm{cm}^{3} \text {. }\end{array}$ \\
\hline
\end{tabular}


Table 2. Rock mass quality based on RMR [10], GSI [12], correlation of RMR and GSI at the research location, correlation of RMR and GSI [13], and correlation of RMR and GSI [4]

\begin{tabular}{|c|c|c|c|c|c|c|c|c|c|c|c|c|c|}
\hline \multirow{3}{*}{ Borehole } & \multirow{3}{*}{ Lithology } & \multirow{4}{*}{$\begin{array}{c}\text { Weathering } \\
\text { Degree }\end{array}$} & \multirow{3}{*}{\multicolumn{2}{|c|}{ Depth (m) }} & \multicolumn{9}{|c|}{ Rock Mass Quality } \\
\hline & & & & & \multirow{3}{*}{$\begin{array}{l}\text { GSI } \\
\text { Hoek } \\
\text { et al. } \\
{[12]}\end{array}$} & \multirow{2}{*}{\multicolumn{2}{|c|}{\begin{tabular}{c|c} 
RMR & $\begin{array}{c}\text { Mass } \\
\text { Quality }\end{array}$ \\
Bieniawski [10]
\end{tabular}}} & \multirow{2}{*}{\multicolumn{2}{|c|}{\begin{tabular}{c|c} 
RMR & $\begin{array}{c}\text { Mass } \\
\text { Quality }\end{array}$ \\
Research \\
Location
\end{tabular}}} & RMR & $\begin{array}{c}\text { Rock } \\
\text { Mass } \\
\text { Quality }\end{array}$ & RMR & $\begin{array}{c}\text { Rock } \\
\text { Mass } \\
\text { Quality }\end{array}$ \\
\hline & & & & & & & & & & \multicolumn{2}{|c|}{$\begin{array}{c}\text { Quality } \\
\text { Hoek \& Brown } \\
{[13]}\end{array}$} & \multicolumn{2}{|c|}{\begin{tabular}{l|l} 
& Quality \\
&
\end{tabular}} \\
\hline $\mathrm{T}-17 \mathrm{~B}$ & $\begin{array}{c}\text { Residual } \\
\text { soil }\end{array}$ & & 0 & 1.5 & & & & & & & & & \\
\hline $\mathrm{T}-17 \mathrm{~B}$ & $\begin{array}{c}\text { Calcareous } \\
\text { sandstone }\end{array}$ & $\begin{array}{c}\text { Highly } \\
\text { weathered }\end{array}$ & 1.5 & 4 & 23.4 & 34.3 & Poor & 32.9 & Poor & 28.4 & Poor & 26.2 & Poor \\
\hline $\mathrm{T}-17 \mathrm{~B}$ & $\begin{array}{c}\text { Calcareous } \\
\text { sandstone }\end{array}$ & $\begin{array}{c}\text { Highly } \\
\text { weathered }\end{array}$ & 4 & 9 & 33.4 & 39.0 & Poor & 38.1 & Poor & 38.4 & Poor & 32.1 & Poor \\
\hline $\mathrm{T}-17 \mathrm{~B}$ & $\begin{array}{l}\text { Calcareous } \\
\text { sandstone }\end{array}$ & $\begin{array}{l}\text { Moderate } \\
\text { weathered }\end{array}$ & 9 & 13 & 48.7 & 48.3 & Fair & 46.1 & Fair & 53.7 & Fair & 41.1 & Fair \\
\hline $\mathrm{T}-17 \mathrm{~B}$ & $\begin{array}{l}\text { Calcareous } \\
\text { sandstone }\end{array}$ & $\begin{array}{c}\text { Slightly } \\
\text { weathered }\end{array}$ & 13 & 45 & 84.5 & 63.3 & Good & 64.8 & Good & 89.5 & $\begin{array}{l}\text { Very } \\
\text { Good }\end{array}$ & 62.2 & Good \\
\hline $\mathrm{T}-17 \mathrm{~B}$ & sandstone & $\begin{array}{c}\text { Slightly } \\
\text { weathered }\end{array}$ & 45 & 50 & 86.9 & 65.0 & Good & 66.0 & Good & 91.9 & $\begin{array}{l}\text { Very } \\
\text { Good }\end{array}$ & 63.6 & Good \\
\hline $\mathrm{T}-16 \mathrm{~B}$ & $\begin{array}{c}\text { Residual } \\
\text { soil }\end{array}$ & & 0 & 5.5 & & & & & & & & & \\
\hline $\mathrm{T}-16 \mathrm{~B}$ & $\begin{array}{l}\text { Calcareous } \\
\text { sandstone }\end{array}$ & $\begin{array}{c}\text { Highly } \\
\text { weathered }\end{array}$ & 5.5 & 22 & 35.8 & 34.5 & Poor & 39.4 & Poor & 40.8 & Poor & 33.5 & Poor \\
\hline $\mathrm{T}-16 \mathrm{~B}$ & $\begin{array}{l}\text { Calcareous } \\
\text { sandstone }\end{array}$ & $\begin{array}{c}\text { Moderate } \\
\text { weathered }\end{array}$ & 22 & 28 & 74.4 & 56.5 & Fair & 59.5 & Good & 79.4 & $\begin{array}{l}\text { Very } \\
\text { Good }\end{array}$ & 56.3 & Good \\
\hline $\mathrm{T}-16 \mathrm{~B}$ & $\begin{array}{c}\text { Calcareous } \\
\text { sandstone }\end{array}$ & $\begin{array}{c}\text { Slightly } \\
\text { weathered }\end{array}$ & 28 & 55 & 85.5 & 64.5 & Good & 65.3 & Good & 90.5 & $\begin{array}{l}\text { Very } \\
\text { Good }\end{array}$ & 62.8 & Good \\
\hline $\mathrm{T}-16 \mathrm{~B}$ & sandstone & $\begin{array}{c}\text { Slightly } \\
\text { weathered }\end{array}$ & 55 & 60 & 86.3 & 64.0 & Good & 65.7 & Good & 91.3 & $\begin{array}{l}\text { Very } \\
\text { Good }\end{array}$ & 63.3 & Good \\
\hline $\mathrm{T}-13 \mathrm{~B} 1$ & $\begin{array}{c}\text { Residual } \\
\text { soil }\end{array}$ & & 0 & 2.8 & & & & & & & & & \\
\hline $\mathrm{T}-13 \mathrm{~B} 1$ & $\begin{array}{l}\text { Calcareous } \\
\text { sandstone }\end{array}$ & $\begin{array}{c}\text { Highly } \\
\text { weathered }\end{array}$ & 2.8 & 5 & 22.5 & 32.0 & Poor & 32.5 & Poor & 27.5 & Poor & 25.7 & Poor \\
\hline $\mathrm{T}-13 \mathrm{~B} 1$ & $\begin{array}{l}\text { Calcareous } \\
\text { sandstone }\end{array}$ & $\begin{array}{l}\text { Moderate } \\
\text { weathered }\end{array}$ & 5 & 11 & 48.5 & 51.0 & Fair & 46.0 & Fair & 53.5 & Fair & 41.2 & Fair \\
\hline T-13B1 & $\begin{array}{l}\text { Calcareous } \\
\text { sandstone }\end{array}$ & $\begin{array}{c}\text { Slightly } \\
\text { weathered }\end{array}$ & 11 & 33 & 74.4 & 61.9 & Good & 59.5 & Good & 79.4 & Good & 56.3 & Good \\
\hline $\mathrm{T}-13 \mathrm{~B} 1$ & $\begin{array}{c}\text { Calcareous } \\
\text { sandstone }\end{array}$ & $\begin{array}{c}\text { Slightly } \\
\text { weathered }\end{array}$ & 33 & 50 & 85.4 & 67.6 & Good & 65.2 & Good & 90.4 & $\begin{array}{l}\text { Very } \\
\text { Good }\end{array}$ & 62.7 & Good \\
\hline $\mathrm{T}-11 \mathrm{~B}$ & $\begin{array}{c}\text { Residual } \\
\text { soil }\end{array}$ & & 0 & 1.5 & & & & & & & & & \\
\hline $\mathrm{T}-11 \mathrm{~B}$ & $\begin{array}{l}\text { Calcareous } \\
\text { sandstone }\end{array}$ & $\begin{array}{c}\text { Highly } \\
\text { weathered }\end{array}$ & 1.5 & 7 & 21.7 & 32.0 & Poor & 32.1 & Poor & 26.7 & Poor & 25.3 & Poor \\
\hline $\mathrm{T}-11 \mathrm{~B}$ & $\begin{array}{l}\text { Calcareous } \\
\text { sandstone }\end{array}$ & $\begin{array}{c}\text { Moderate } \\
\text { weathered }\end{array}$ & 7 & 18 & 48.4 & 47.8 & Fair & 46.0 & Fair & 53.4 & Fair & 41.1 & Fair \\
\hline $\mathrm{T}-11 \mathrm{~B}$ & $\begin{array}{l}\text { Calcareous } \\
\text { sandstone }\end{array}$ & $\begin{array}{c}\text { Slightly } \\
\text { weathered }\end{array}$ & 18 & 40 & 65.7 & 52.1 & Fair & 55.0 & Fair & 70.7 & Good & 51.2 & Fair \\
\hline $\mathrm{T}-15 \mathrm{~B}$ & $\begin{array}{c}\text { Residual } \\
\text { soil }\end{array}$ & & 0 & 5 & & & & & & & & & \\
\hline $\mathrm{T}-15 \mathrm{~B}$ & $\begin{array}{l}\text { Calcareous } \\
\text { sandstone }\end{array}$ & $\begin{array}{c}\text { Highly } \\
\text { weathered }\end{array}$ & 5 & 9 & 31.7 & 38.0 & Poor & 37.3 & Poor & 36.7 & Poor & 31.1 & Poor \\
\hline $\mathrm{T}-15 \mathrm{~B}$ & $\begin{array}{l}\text { Calcareous } \\
\text { sandstone }\end{array}$ & $\begin{array}{c}\text { Moderate } \\
\text { weathered }\end{array}$ & 9 & 30 & 48.4 & 46.9 & Fair & 46.0 & Fair & 53.4 & Fair & 41.1 & Fair \\
\hline
\end{tabular}

We acknowledge PT. Hutama Karya (Persero) and PT. Adhi Karya (Persero) Tbk to give us permission in conducting research at the Sigli-Aceh toll road tunnel 1. Thank you to Dr. Hendy Setiawan for guiding and providing valuable inputs in refining the manuscript. This research is financially supported by PT. Hutama Karya (Persero) in the scheme of a superspecialist program by the Ministry of Public Works and Housing year 2020.

\section{References}

1. Parker, Harvey W, Good for sustainable development, and vice versa, in International Tunnelling Association (ITA), Singapore (2004)

2. B. Brahmantyo and B. Salim, Jurnal Geoaplika 1,2:071-078 (2006)
3. D.U. Deere and D. W. Deere, Rock quality designation (RQD) after twenty years, 11-19 (US Army Corps of Engineers, Washington,1989)

4. Q. Zhang, X. Huang, H. Zhu, J. Li, Tunn. Undergr. Sp. Tech, 83:73-81 (2019)

5. J.D. Bennet, D.McC. Bridge, N.R. Cameron, A. Djunuddin, S.A. Ghazali, D.H. Jeffery, W. Kartawa, W. Keats, N.M.S. Rock, S.J. Thomson, R. Whandoyo, Peta geologi lembar Banda Aceh, Sumatra (1981)

6. PUSGEN, Indonesia earthquake source and hazard map (Peta sumber dan bahaya gempabumi Indonesia)(2017)

7. ISRM, Int. J. Rock Mech. Min. Sci. Geomech. Abstr. 15:319-368 (1978) 
8. SNI 03-3637-1994, Method of testing the unit weight of fine-grained soil with the test object mold, 1-4 (Public Works Research and Housing, Indonesia, 1994)

9. SNI 2825, The instruction of uniaxial compressive strength test for rock, 1-8 (Association of National Standardization, Indonesia, 2008)

10. Z. T. Bieniawski, Engineering rock mass classifications: a complete manual for engineers and geologists in mining, civil, and petroleum engineering (Wiley, New York 1989)

11. P. Marinos and E. Hoek, GSI: a geologically friendly tool for rock mass strength estimation, in Proceeding GeoEng2000 Conference, Melbourne, 1422-1442 (2000)

12. E. Hoek, T. G. Carter, M. S. Diederichs, Quantification of the geological strength index chart, in US Rock Mechanics/Geomechanics Symposium, San Francisco (2013)

13. E. Hoek and E. T. Brown, Int. J. Rock Mech. Min. Sci. 34,8:1165-1186 (1997)

14. B. Celada, I. Tardáguila, P. Varona, A. Rodrígueza, Z. T. Bieniawski, Innovating tunnel design by an improved experience-based RMR system in Proceedings of the World Tunnel Congress, 1-9 (2014)

15. J.C. Gamble, Durability-plasticity classification of shales and other argillaceous rocks. University of Illinois, Urbana-Champaign (1971) 